\title{
Synthesis, Characterization and Antibacterial Activity of Mixed Ligands of Schiff Base and It's Metal(II) Complexes Derived from Ampicilin, 3-Aminophenol and Benzaldehyde
}

\author{
Nasiru Pindiga Yahaya*, Muhammad Sani Mukhtar \\ Department of Chemistry, Faculty of Science, Gombe State University, Gombe, Nigeria \\ Email address: \\ npy500@yahoo.com (N. P. Yahaya) \\ ${ }^{*}$ Corresponding author \\ To cite this article: \\ Nasiru Pindiga Yahaya, Muhammad Sani Mukhtar. Synthesis, Characterization and Antibacterial Activity of Mixed Ligands of Schiff Base \\ and It's Metal(II) Complexes Derived from Ampicilin, 3-Aminophenol and Benzaldehyde. Science Journal of Chemistry. \\ Vol. 9, No. 1, 2021, pp. 9-13. doi: 10.11648/j.sjc.20210901.12
}

Received: November 8, 2020; Accepted: November 18, 2020; Published: February 10, 2021

\begin{abstract}
Schiff base ligands were synthesis via a condensation of the ligands in methanol in 1:1:1 molar ratio reactions. The transition metal(II) complexes were formed by the reaction of $\mathrm{Co}, \mathrm{Cu}, \mathrm{Mn}, \mathrm{Fe}$ with the Schiff base and ampicillin and they were characterized via FTIR, electronic spectra, melting points, solubility and molar conductance. The invitro antibacterial activities of the complexes were tested using four bacterial strains; gramnegative; (Escherichiacoli, salmonellatyphi) and grampositive; (staphylococcus pyogenes and staphylococcus aureus). The complexes were formed in good yield and they have various shades of colors and sharp melting points. The IR spectrum of the HL (Table4) displays a new at $(1651) \mathrm{cm}^{-1}$ which is due to $v(\mathrm{HC}=\mathrm{N})$ group of the azomethine stretching vibrations of the ligand, on complexation these band has been shifted to lower frequencies (1651), (1621), (1651), and (1627) $\mathrm{cm}^{-1}$ for complexes [Co(Ampi)(3AMPB)Cl], [Cu(Ampi)(3AMPB)], [Mn(Ampi)(3AMP)Cl] and [Fe(Ampi)(3AMPB)] respectively. The overlap band at $(1688) \mathrm{cm}^{-1}$ stretching vibration is due to $v(\mathrm{C}=\mathrm{O})$ for $\beta$-Lactam group, these band has been shifted to lower frequency at $(1370-1425) \mathrm{cm}^{-1}$ for complexes showing that the coordination is through the Oxygen atom of $\beta$-Lactam group. The band sat (525), (526), (524) and $(526) \mathrm{cm}^{-1}$ were assigned to $v(\mathrm{M}-\mathrm{O})$ for compounds of Co, $\mathrm{Cu}, \mathrm{Mn}, \mathrm{Fe}$, indicating that to the carbocyclic oxygen, and oxygen of $\beta$-Lactam group of the ligand are involved in coordination with metalions. The bands at (659), (669), (660), and (698) $\mathrm{cm}^{-1}$ were assigned to $v(\mathrm{M}-\mathrm{N})$ for compounds $\mathrm{Co}, \mathrm{Cu}, \mathrm{Mn}, \mathrm{Fe}$ respectively, indicating that the nitrogen is involved in coordination with metal ions. The electronic spectral data of the complexes suggest an Octahedral and tetrahedral geometry for all the complexes. The molarconductivity indicates that the synthesized complexes are all non-electrolytes and soluble in protic solvent such as methanol and ethanol. The invitro antibacterial screening of Schiff base and its metal complexes showed that they are potential antibacterial agents against the tested microorganisms
\end{abstract}

Keywords: SchiffBase, 3-aminophenol, Benzaldehyde, Ampiciln, Metal Complexes, Antibacterial Activity

\section{Introduction}

Schiff bases and their complexes are versatile compounds synthesized from the condensation of an amino compound with carbonyl compounds and widely used for industrial purposes and also exhibit a broad range of biological activities including antifungal, antibacterial, antimalarial, antiproliferative, anti-inflammatory, antiviral, and antipyretic properties [1] Schiff base are the compound containing azomethine group $(-\mathrm{HC}=\mathrm{N}-)$. The acid/base catalysis or heating is employed for the synthesis of Schiff bases as their reactions are mostly reversible [2].

The aim of the research is to synthesize, characterize and evaluate the antibacterial activity of the synthesized Schiff base and its metal (II) complexes of $\mathrm{Fe}(\mathrm{II}), \mathrm{Co}(\mathrm{II}), \mathrm{Cu}(\mathrm{II})$ and $\mathrm{Mn}(\mathrm{II})$ ions .

While the specific objectives of the study will be to:

i. Prepare Schiff base using a mixed ligands of 3aminophenol and Benzaldehyde.

ii. Synthesize Schiff base metal complexes of Fe(II), $\mathrm{Co}(\mathrm{II}), \mathrm{Cu}(\mathrm{II})$ and $\mathrm{Mn}(\mathrm{II})$ ions.

iii. Synthesize Schiff base and ampicillin with its metal 
complexes of $\mathrm{Fe}(\mathrm{II}), \mathrm{Zn}$ (II), $\mathrm{Co}(\mathrm{II}), \mathrm{Cu}(\mathrm{II}) \mathrm{Ni}(\mathrm{II})$ and $\mathrm{Mn}(\mathrm{II})$ ions.

iv. Determine the physico-chemical properties of Schiff base and its metal complexes using different analytical technique like melting point, FTIR, conductivity, solubility test and UV/Visible spectrophotometer.

v. Study the antibacterial activity of the Schiff base and it's metal(II) complexes.

\section{Materials and Method}

All chemicals, reagents and drug that were used in this research are of Analar grade. The metals used are; $\mathrm{NiCl}_{2} \cdot 6 \mathrm{H}_{2} \mathrm{O}, \mathrm{ZnCl}_{2}, \mathrm{FeSO}_{4}, 3$-aminophenol and Benzaldehyde are the ligands that were used in the research which were obtained from Department of Chemistry, Gombe State University, Nigeria. For the conduct of this research routine laboratory apparatus were used such as; Fourier Transform Spectroscopy (FT-IR), UV/Visible Spectrophotometer, stop watch, conductivity meter, melting point apparatus, Hot plate and magnetic stirrer, Oven, Weighing Balance, Auto clave, pH Meter, Petri Dishes, Pestle and Mortar, Water Bath

\subsection{Synthesis of Schiff Base 3-aminophenol Benzaldehyde $H L^{1}$}

The Schiff base was synthesized by a slight modification of literature [3]. This is done by the condensation of methanolic solution of benzaldehyde $(0.005 \mathrm{~mol}, 0.53 \mathrm{~g})$ with 3 -aminophenol $(0.005 \mathrm{~mol}, 0.55 \mathrm{~g})$ in $20 \mathrm{ml}$ of methanol $(1: 1$ molar ratio). The resulting mixture was then refluxed for $1 \mathrm{hr}$. the precipitate was separated by a suction filtration. It was recrystallized from ethanol and dried, and preserve in a desiccator for $24 \mathrm{hr}$ over $\mathrm{CaCl}_{2}$

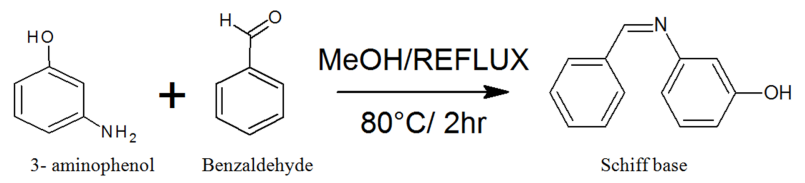

Figure 1. SynthesizeSchiffbaseof3-aminophenolbenzaldehyde.

Synthesis of Schiff base, ampicillinandmetal(II)complexes

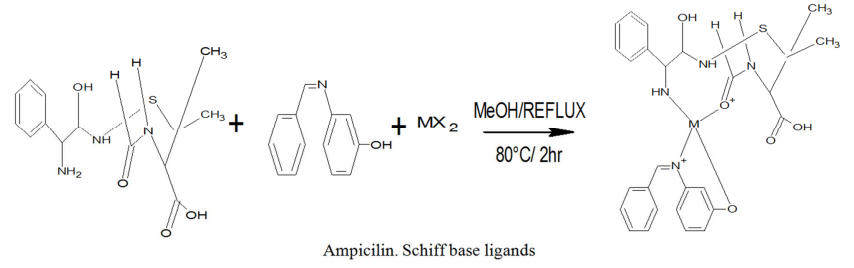

Figure 2. Synthesize Schiff base and metal(II) complex.

Where $\mathrm{M}=\mathrm{FeSO}_{4}, \mathrm{NiCl}_{2} \cdot 6 \mathrm{H}_{2} \mathrm{O}, \mathrm{ZnCl}_{2}$.

The complexes were synthesized using (1:1:1 molar ratio). A solution of the Schiff base (HL) $(0.001 \mathrm{~mol}, 0.43 \mathrm{~g})$ in $10 \mathrm{ml}$ of methanol and a solution of ampicillin (Ampi) $(0.001 \mathrm{~mol}$, $0.35 \mathrm{~g}$ ) in $10 \mathrm{ml}$ methanol, were added to a stirred solution of $\left(0.001 \mathrm{~mol}, \quad 0.16 \mathrm{~g}\right.$ of $\mathrm{CuSO}_{4} .5 \mathrm{H}_{2} 0,0.001 \mathrm{~mol}, \quad 0.24 \mathrm{gof}$
$\mathrm{CoCl}_{2} \cdot 6 \mathrm{H}_{2} 0,0.001 \mathrm{~mol}, 0.15 \mathrm{~g}$ of $\mathrm{FeSO}_{4}, 0.001 \mathrm{~mol}, 0.20 \mathrm{~g}$ of $\mathrm{MnCl}_{2} \cdot 4 \mathrm{H}_{2} 0$ )in $5 \mathrm{ml}$ of methanol. The resulting mixtures were heated under reflux for $3 \mathrm{hr}$. then the mixture was filtered by suction and the precipitate was washed with excess of ethanol and dried at room temperature for $24 \mathrm{hr}$ in a desiccator over $\mathrm{CaCl}_{2}$ [4].

\subsection{Characterization of Schiff Base and Its Metal (II) Complexes}

Characterization involve simple fingerprint of compounds already known, or more extensive investigation designed to establish the formula and structure of a new compound [5]. The Schiff base and its metal complexes was characterized by using different physico-chemical techniques like Melting point, U/Visible spectrophotometer, FTIR, Conductivity, Solubility test.

\subsection{Antibacterial Activity}

The four bacterial species were used two gram-negative (Escherichia coli, Salmonella typhi) and two gram-positive (Staphylococcus aureus, Streptococcus pyrpgens), were obtained from pharmaceutical microbiology Department of the Gombe state University. The antibacterial activity of the ligand and the complexes was determined by the disc diffusion technique. The compounds were screened invitro. A $1 \mathrm{mg} / \mathrm{ml}$ solution in DMSO was used. Ceftriaxone and subactam were used as standard reference drug. The bacterium was maintained on nutrient agar and the agar media was incubated for different microorganism culture tests. After $24 \mathrm{hrs}$ of incubation at $37^{\circ} \mathrm{C}$ for the bacteria, the diameters of zone of inhibition $(\mathrm{mm})$ thus formed around each disc containing the test compound was measured [3].

\section{Results and Discussion}

\subsection{Physical Characteristics and Analytical Data of Ligands/Complexes}

In general, the complexes of [Co(Ampi)(3AMPB)Cl], [Cu(Ampi)(3AMPB)], [Mn(Ampi)(3AMP)Cl] and [Fe(Ampi)(3AMPB)] were obtained by heating under reflux of respective metal salts with HL and ampicillin in 1:1:1 molar ratio. The Schiff base and its metal(II) complexes shows various shades of colors ranging from Milk, Milk, Yellow-green, Milk, Grey for The HL and the complexes of $\mathrm{Co}, \mathrm{Cu}, \mathrm{Mn} \mathrm{Fe}$ respectively. The $\mathrm{HL}$ and the complexes of $\mathrm{Co}, \mathrm{Cu}, \mathrm{Mn}, \mathrm{Fe}$ obtained gave a sharp melting point indicating the isolation of fairly pure complexes $(<300)$, (286-288), (283-284), (279-283), (285-287) ${ }^{\circ} \mathrm{C}$ of HL, Co, $\mathrm{Cu}, \mathrm{Mn}, \mathrm{Fe}$ respectively [6]. The Schiff base and its metal (II) complexes were prepared in good yield, ranging from 50$80 \%$ (7). The molar conductance of the complexes was determined in DMSO. It was found to be 4.1, 6.1, 3.1, 13.2 and $5.7 \Omega^{-1} \mathrm{~cm}^{-2} \mathrm{~mol}^{-1}$ for the $\mathrm{Co}, \mathrm{Cu}, \mathrm{Mn}, \mathrm{Fe}$ complexes respectively. These low values suggested their nonelectrolytic nature $[7,8]$. 
Table 1. Physical Characteristic sand Analytical Data of Ligands/Complexes.

\begin{tabular}{|c|c|c|c|c|c|}
\hline Compounds & MOL. WGT & COLOR & M. $\mathbf{P}^{\circ} \mathrm{C}$ & \%YIELD & Molarconductivity $\Omega^{-1} \mathrm{~cm}^{-2} \mathrm{~mol}^{-1}$ \\
\hline $\mathrm{HL}$ & 458.393 & MILK & $<300$ & 75 & 4.2 \\
\hline Co(Ampi)(3AMPB)Cl & 552.823 & MILK & $286-288$ & 80 & 6.1 \\
\hline $\mathrm{Cu}(\mathrm{Ampi})(3 \mathrm{AMPB})$ & 522.393 & YELLOW-GREEN & $283-284$ & 78 & 3.1 \\
\hline Mn(Ampi)(3AMP)Cl & 548.893 & MILK & $279-283$ & 50 & 13.2 \\
\hline $\mathrm{Fe}(\mathrm{Ampi})(3 \mathrm{AMPB})$ & 514.393 & GREY & $285-287$ & 65 & 5.7 \\
\hline
\end{tabular}

WhereHL $^{1}=$ Schiffbaseof3Aminophenolbenzaldehydeandampicillinligands, MOL. WGT=Molecularweight, $\mathrm{M}$. $\mathrm{P}=$ meltingpoints.

\subsection{Solubility Test of the Complexes}

The solubility of the complexes of [Co(Ampi)(3AMPB)Cl], [Cu(Ampi)(3AMPB)], [Mn(Ampi)(3AMP)Cl] and [Fe(Ampi)(3AMPB)] was studied in various solvent in both hot and cool process. The complexes are not soluble in water, pet. ether and diethyl ether (cool and hot), it is sparingly soluble in chloroform. But all the complexes are soluble in $\mathrm{MeOH}(\mathrm{cool}$ and hot), $\mathrm{EtOH}$ (hot) and DMSO(cool and hot). Their solubility is as results of the interaction between the hydrogen ion in the complexes and the oxygen atom in the solvent which results in the formation of hydrogen bond (4) and [9].

Table 2. Solubility Test of the Complexes.

\begin{tabular}{|c|c|c|c|c|c|c|c|c|c|c|c|c|c|c|c|c|}
\hline \multirow{2}{*}{ Compound } & \multicolumn{2}{|c|}{ DIST.H $_{2} \mathrm{O}$} & \multicolumn{2}{|c|}{ МeOH } & \multicolumn{2}{|c|}{ EtOH } & \multicolumn{2}{|c|}{ Acetone } & \multicolumn{2}{|c|}{ Chloroform } & \multicolumn{2}{|c|}{ P. Ether } & \multicolumn{2}{|c|}{ D. Ether } & \multicolumn{2}{|c|}{ DMSO } \\
\hline & $\mathbf{C}$ & $\mathbf{H}$ & $\mathrm{C}$ & $\mathbf{H}$ & $\mathbf{C}$ & $\mathbf{H}$ & $\mathrm{C}$ & $\mathbf{H}$ & $\mathbf{C}$ & $\mathbf{H}$ & $\mathbf{C}$ & $\mathbf{H}$ & $\mathbf{C}$ & $\mathbf{H}$ & $\mathbf{C}$ & $\mathbf{H}$ \\
\hline $\mathrm{Co}(\mathrm{Ampi})(3 \mathrm{AMPB})$ & NS & NS & $\mathrm{S}$ & $\mathrm{S}$ & SS & $\mathrm{S}$ & $\mathrm{S}$ & $\mathrm{S}$ & $\mathrm{S}$ & $\mathrm{S}$ & NS & NS & NS & NS & $\mathrm{S}$ & $\mathrm{S}$ \\
\hline $\mathrm{Cu}$ (Ampi)(3AMPB) & NS & NS & SS & $\mathrm{S}$ & SS & $\mathrm{S}$ & SS & $\mathrm{S}$ & SS & SS & SS & SS & SS & SS & $\mathrm{S}$ & $\mathrm{S}$ \\
\hline Mn(Ampi)(3AMPB) & NS & NS & SS & SS & SS & $\mathrm{S}$ & SS & $\mathrm{S}$ & NS & NS & NS & NS & NS & NS & SS & $\mathrm{S}$ \\
\hline $\mathrm{Fe}(\mathrm{Ampi})(3 \mathrm{AMPB})$ & NS & NS & SS & $\mathrm{S}$ & SS & SS & SS & $\mathrm{S}$ & NS & NS & NS & NS & NS & NS & SS & $\mathrm{S}$ \\
\hline
\end{tabular}

$\mathrm{HL}=$ Schiff base of 3Aminophenol benzaldehyde and ampicilin ligands, Where $\mathrm{C}=\mathrm{Cool}$, $\mathrm{H}=$ hot, $\mathrm{S}=\mathrm{Soluble}$, SS=Sparingly Soluble, NS=Not Soluble, $\mathrm{MeOH}=$ Methanol, EtOH=Ethanol, Dist. $\mathrm{H}_{2} \mathrm{O}=$ Distilledwater, $\quad$ P. Ether=Petroleumether, D. Ether=DiethylEther, DMSO=Dimethylsulphoixed, $3 \mathrm{AMPB}=$ Schiffbase of 3 Aminophenolbenzaldehyde, Ampi=Ampiciline

\subsection{Electronic Spectral Data of Ligands and Complexes}

The electronic spectrum of the ligandHL was been measured in DMSO solution between 200-1100 nm at room temperature. In the spectrum of the Schiff base ligand HL, the absorption band observed at $(212 \mathrm{~nm})\left(47169 \mathrm{~cm}^{-1}\right.$, which assigned to ( $\pi-\pi$ transition. The UV-Vis spectrum for the complexes ([Co(Ampi)(3AMPB)Cl], [Cu(Ampi)(3AMPB)],
[Mn(Ampi)(3AMP)Cl] and [Fe(Ampi)(3AMPB)]) shows a band at $(335 \mathrm{~nm})\left(29850 \mathrm{~cm}^{-1}\right),(267 \mathrm{~nm})\left(37453 \mathrm{~cm}^{-1}\right)$, $(280 \mathrm{~nm})\left(35714 \mathrm{~cm}^{-1}\right)$ and $(323 \mathrm{~nm})\left(30959 \mathrm{~cm}^{-1}\right)$ for the complexes of [Co(Ampi)(3AMPB)Cl], [Cu(Ampi)(3AMPB)], [Mn(Ampi)(3AMP)Cl $]$ and [Fe(Ampi)(3AMPB)] which show $\left(\mathrm{T}_{1} \mathrm{~g}-\mathrm{A}_{2} \mathrm{~g}\right),\left(\mathrm{T}_{2} \mathrm{~g}-\mathrm{Eg}\right),\left(\mathrm{A}_{2} \mathrm{~g}-\right.$ $\left.\mathrm{T}_{2} \mathrm{~g}\right)$ and $\left(\mathrm{T}_{2} \mathrm{~g}-\mathrm{Eg}\right)$ transition. The Transitions, similar to those found for distorted octahedral complexes $[4,10,11]$.

Table 3. Electronic Spectral Data of Ligand sand Complexes.

\begin{tabular}{|c|c|c|c|c|}
\hline Compound & Absorptioninnm & Absorptionincm $^{-1}$ & Bandassignment & Geometry \\
\hline HL & 212 & 47169 & $n-n^{*}$ & \\
\hline $\mathrm{Co}($ Ampi)(3AMPB)Cl & 335 & 29850 & $\mathrm{~T}_{1} \mathrm{~g}-\mathrm{A}_{2} \mathrm{~g}$ & Octahedral \\
\hline $\mathrm{Cu}(\mathrm{Ampi})(3 \mathrm{AMPB})$ & 267 & 37453 & $\mathrm{~T}_{2} \mathrm{~g}-\mathrm{Eg}$ & Tetrahedral \\
\hline $\mathrm{Mn}($ Ampi)(3AMP)Cl & 280 & 35714 & $\mathrm{~A}_{2} \mathrm{~g}-\mathrm{T}_{2} \mathrm{~g}$ & Octahedral \\
\hline $\mathrm{Fe}(\mathrm{Ampi})(3 \mathrm{AMPB})$ & 323 & 30959 & $\mathrm{~T}_{2} \mathrm{~g}-\mathrm{Eg}$ & Tetrahedral \\
\hline
\end{tabular}

$*=$ Transition state

\subsection{Major FTIR Spectral Data of Ligands and Complexes}

The IR spectrum of the HL (Table 4) displays a new at (1651) $\mathrm{cm}^{-1}$ which is due to $v(\mathrm{HC}=\mathrm{N}-)$ group of the azomethine stretching vibrations of the ligand, on complexation these band has been shifted to lower frequencies (1651), (1621), (1651), and (1627) $\mathrm{cm}^{-1}$ for complexes [Co(Ampi) (3AMPB)Cl], [Cu(Ampi) (3AMPB)], [Mn(Ampi) (3AMP)Cl] and [Fe(Ampi) (3AMPB)] respectively. The overlap band at $(1688) \mathrm{cm}^{-1}$ stretching vibration is due to $v(\mathrm{C}=\mathrm{O})$ for $\beta$-Lactam group, these band has been shifted to lower frequency at $(1370-1425) \mathrm{cm}^{-1}$ for complexes showing that the coordination is through the Oxygen atom of $\beta$-Lactam group. The bands at (525), (526), (524) and (526) $\mathrm{cm}^{-1}$ were assigned to $v(\mathrm{M}-\mathrm{O})$ for compounds of $\mathrm{Co}, \mathrm{Cu}, \mathrm{Mn}, \mathrm{Fe}$, indicating that to the carbocyclic oxygen, and oxygen of $\beta$-Lactam group of the ligand are involved in coordination withmetal ions. The bands at (659), (669), (660), and (698) $\mathrm{cm}-1$ were assigned to $v(\mathrm{M}-\mathrm{N})$ for compounds $\mathrm{Co}, \mathrm{Cu}, \mathrm{Mn}, \mathrm{Fe}$ respectively, indicating that the nitrogen is involved in coordination with metal ions [4, 12, 13]. 
Table 4. Major FTIR Spectral Data of Ligands and Complexes.

\begin{tabular}{lllllllllll}
\hline Compound & $\mathbf{v}(\mathbf{N}-\mathbf{H}) \mathbf{P}$ & $\mathbf{v}(\mathbf{N}-\mathbf{H}) \mathbf{S}$ & $\mathbf{V}(\mathbf{C}-\mathbf{C})$ & $\mathbf{V}(\mathbf{C}=\mathbf{C})$ & $\mathbf{V}(\mathbf{C}=\mathbf{N})$ & $\mathbf{V}(\mathbf{C}-\mathbf{N})$ & $\mathbf{V}(\mathbf{C}-\mathbf{S})$ & $\mathbf{V}(\mathbf{C}-\mathbf{H})$ & $\mathbf{V}(\mathbf{M}-\mathbf{N})$ & $\mathbf{V}(\mathbf{M}-\mathbf{O})$ \\
\hline HL & 3541 & 3270 & 2384 & 1658 & 1651 & 1450 & & & - & - \\
Co(Ampi)(3AMPB) & 3572 & 3491 & 1135 & 1370 & 1651 & 1211 & 576 & 2384 & 659 & 525 \\
Cu(Ampi)(3AMPB) & 3541 & 3401 & 1119 & 1370 & 1621 & 1493 & 576 & - & 669 & 526 \\
Mn(Ampi)(3AMP) & 3572 & 3492 & 1210 & 1370 & 1651 & 1210 & 576 & 2380 & 660 & 524 \\
Fe(Ampi)(3AMPB) & 3485 & 3319 & 1134 & 1425 & 1627 & 1450 & 576 & - & 698 & 526 \\
\hline
\end{tabular}

Ampi=ampicillin, $3 \mathrm{AMPB}=3$ Aminophenolbenzaldehyde.

\subsection{Antibacterial Activity of the Ligands/Complexes of (3AMPB)}

The antibacterial activity of the Metal complexes of Schiff base derived from (HL) and $\mathrm{Co}, \mathrm{Cu}, \mathrm{Mn}$ Fe showed a good antibacterial activity against Gram-negative (Escherichia coli and Salmonella typhi,). The $\mathrm{Co}, \mathrm{Cu}, \mathrm{Mn} F \mathrm{Fe}$ complexes caused strong inhibition for E. coli and Salmonella typhi. The importance of these lies in the fact that, these complexes could be applied fairly in the treatment of some common diseases caused by E. coli and Salmollatyphi. However, Co, $\mathrm{Cu}, \mathrm{Mn} \mathrm{Fe}$ complexes were specialized in inhibiting Grampositive bacterial strains (Staphylococcus auerus andStreptococcus pyrogens). The importance of this unique property of the investigated Schiff base complexes lies in the fact that, it could be applied safely in the treatment of infections caused by any of these particular strain $[1,14,15]$.

Table 5. Antibacterial Activity of the Ligands and Complexes.

\begin{tabular}{|c|c|c|c|c|}
\hline \multirow{3}{*}{ Compounds } & \multicolumn{4}{|c|}{ CONCENTRATION $(\mathrm{mg} / \mathrm{ml})$} \\
\hline & \multicolumn{2}{|l|}{ Gram-negative } & \multicolumn{2}{|l|}{ Gram-positive } \\
\hline & E.Coil $(50 / 100)$ & $\operatorname{Salm}(50 / 100)$ & Staphy $(50 / 100)$ & Strept $(50 / 100)$ \\
\hline HL & $11 / 15$ & $8 / 10$ & $15 / 16$ & $14 / 20$ \\
\hline $\mathrm{Co}(\mathrm{Ampi})(3 \mathrm{AMPB})$ & $18 / 20$ & $6 / 5$ & $17 / 18$ & $11 / 12$ \\
\hline $\mathrm{Cu}$ (Ampi)(3AMPB) & $22 / 25$ & $7 / 9$ & $21 / 20$ & $11 / 15$ \\
\hline Mn(Ampi)(3AMP) & $19 / 20$ & $13 / 12$ & $15 / 19$ & $14 / 17$ \\
\hline $\mathrm{Fe}(\mathrm{Ampi})(3 \mathrm{AMPB})$ & $15 / 17$ & $12 / 14$ & $11 / 17$ & $8 / 10$ \\
\hline
\end{tabular}

Where; E.coli=Escherichiacoli, SALM=Salmonellatyphi, STAPHY=Staphylococcusauerues, STREPT=Streptococcuspyregens, HL=Schiffbase, 3AMPB=3 aminophenolbenzaldehyde, Ampi=Ampicilin.

\section{Conclusion}

The complexes are multi-colored, colors, they have good \% yields with sharp melting point. The electronic spectral data of the complexes suggest an Octahedral and tetrahedral geometry for the complexes. The Results of the molar conductivity indicate that the synthesized complexes are non-electrolytes and 1:2 electrolytes as compared with the electrolytic value of $\mathrm{CaCl}_{2}$. The invitro antibacterial screening of schiff base and its metal complexes showed that they are potential antibacterial agents against the tested

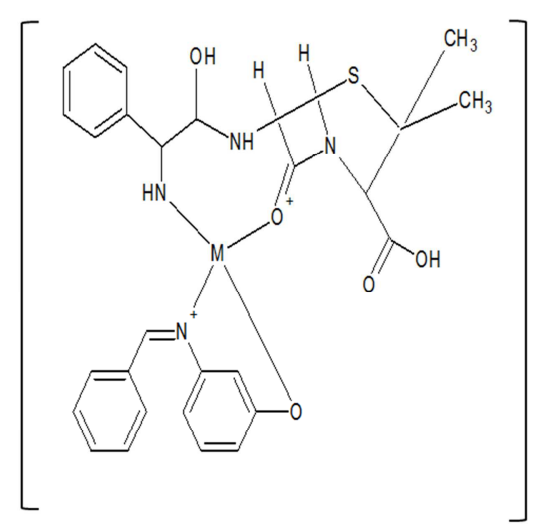

Where $\mathrm{M}=\mathrm{NiCl}_{2}, \mathrm{ZnCl}_{2}$ microorganisms. The formation of the schiff base and its respective metal(II) complexes are shown in Figures 1 and 2 and the proposed Structures based on the data of the synthesize schiff base and the metal (II) complexes are shown in figures 3 and 4 below respectively

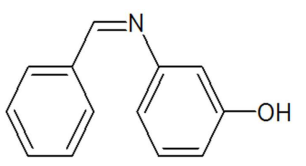

Figure3. ProposedstructureofSchiffbaseof(3AMPB).

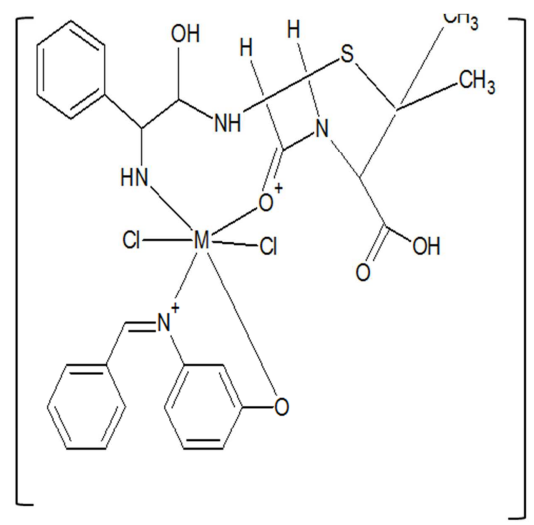

Figure 4. Proposed structure of metal (II) complexes. 


\section{References}

[1] Ahmed, M., Abu-Dief, I. and Mohamed, M. A. (2015), A Review on Versatile Applications of Transition Metal Complexes Incorporating Schiff Bases. SUEF University Journal of Basic and Applied Sciences, (4): 119-133.

[2] Neelima M., Kavitan P and Dinesh K (2013). An overview of biological aspects of Schiff base metal complexes. International Journal of Advancements in Research \& Technology 2 (8), 52.

[3] Fugu, M. B., Ndahi, N. P., Paul, B. B and Mustapha, A. N (2013). Synthesis, characterization, and antimicrobial studies of some vanillin Schiff base metal (II) complexes Journal of Chemical and Pharmaceutical Research, 5 (4): 22-28.

[4] Taghreed, H., Al-Noor, M. R., and Aziz, A. T (2014). synthesis, characterization and antimicrobial activities of [Fe(II), $\mathrm{Co}(\mathrm{II}), \mathrm{Ni}(\mathrm{II}), \mathrm{Cu}(\mathrm{II})$, and $\mathrm{Zn}(\mathrm{II})]$ mixed ligand complexes schiff base derived from ampicillin drug and 4(dimethylamino)benzaldehyde with nicotinamide. International Journal of Technical Research and Applications e-2 (4): 187-192.

[5] Cox, P. A., (2004). Inorganic chemistry laboratory new college oxford UK scientific publisher 2 (2): 111-230.

[6] Emad Y., Ahmed M., Khulood A., Nadia S., Jumat S., Bashar A (2013). Metal complexes of Schiff base: Preparation, characterization and antibacterial activity. Arabian Journal of Chemistry 1 (1) 56-70.

[7] Ahmed, A. A., Umar, H. A, Yunusa, Y. and Adegbemiga, B (2017), Synthesis and Characterization of Cobalt (II) and Nickel (II) Complexes with a Schiff Base Derived from 2aminophenol and 4-(n,n-dimethylamino)benzaldehyde. International Journal of Science and Applied Research (IJSAR) 2 (3) 587-593.

[8] Rehman, W., Baloch, M., and Badshah, A (2008). Synthesis,

Spectral Characterization and Bio-Analysis of some Organotin(IV) Complexes. European Journal of Medicinal Chemistry, 43: 2380-2385.

[9] Mukhtar, H. U., Sani, M. H., Shagal L and Joseph, J. I (2018). Synthesis, Characterization and Antimicrobial Studies of Schiff base Derived from Salicyldehyde and 2,4-dinitrophenyl hydrazine and its Metal (II) Complexes. IOSR Journal of Applied Chemistry (IOSR-JAC) 11 (9):49-53.

[10] Oluwatoosin B., Agbaje, A., Sherifat, M. W., Osowole, A. A (2014). Synthesis, spectroscopic characterisation and antimicrobial activities of some mixed drug metal(II) complexes of Sulfamethoxazole and Paracetamol. Academic editor JC 2 (1) 140-143.

[11] Lever A. B. P., (1984)" Inorganic electronic spectroscopy". Elsevier, New york.

[12] Dhivyapriya, D., Akila, E., Usharani M and. Rajavel R (2012). Synthesis, spectral and biological activity of mixed ligand schiff base complexes derived from salicylaldehyde, Journal of international journal of pharmacy \& technology, (IJPT) 4 (1) $11-12$

[13] Fayad, N. K., Taghreed H. A and Ghanim F. H (2012). Synthesis, characterization and antibacterial activities of Manganese, Cobalt, Iron, Nickel, Zinc, and Cadmium Mixed ligand complexes containing amino acid (L-Valine) and saccharin. Journal of advances in physics theories and application. 9 pp12.

[14] Walaa H., Mahmoud, G. G., Mohamed, M., and El-Dessouky, M. I (2014). Synthesis, Characterization and in vitro Biological Activity of Mixed Transition Metal Complexes of Lornoxicam with 1,10 phenanthroline. Int. J. Electrochem. Sci., (9) 1415-1438.

[15] Nasiru, P. Y., Ndahi, N. P., Bako, L., Mohamad, L. M., Abdullahi,. Z and Yusuf, M (2018). Synthesis and partial characterization of two schiff base ligands with (2 and 4nitroaniline) and their transition metal (II) (Co and $\mathrm{Cu}$ ) complexes. Dutse journal of pure and applied science, 1 (2):584-591. 